К.С. Смеляков ${ }^{1}$, Д.Л. Сандркін ${ }^{1}$, Д.О. Товчиречко ${ }^{1}$, Є.В. Вакулік ${ }^{1}$, Є.М. Дроб ${ }^{2}$

${ }^{1}$ Харківський наиіональний університет радіоелектроніки, Харків

${ }^{2}$ Харківський національний університет Повітряних Сил ім. І. Кожедуба, Харків

\title{
РОЗРОБКА МЕТОДУ ШВИДКОГО ПОШУКУ ЦИФРОВОГО ЗОБРАЖЕННЯ У СХОВИЩАХ ДАНИХ
}

На основі аналізу моделей і принциів роботи сучасних пошукових сервісів, пов'язаних з порівнянням $і$ пошуком зображень, в статті запропоновано шаблон зображення кратної довжини, ефективний алгоритм порівняння шаблонів двох зображень і оцінювання міри схожості ичих зображень, модель зберігання $i$ пошуку зображень на основі використання шаблонів, метод швидкого пошуку зображення у сховищі, на основі використання шаблону. 3 урахуванням запропонованої моделі зображення, інваріантної до найбільш поширених перетворень зображень, запропоновані моделі і методи в комплексі дозволяють ефективно вирішити проблему пошуку зображень у сховищі великих даних по критеріях точності і часу. 3 урахуванням можливих трансформацій $і$ дублювання зображень, наявності великої кількості схожих зображень $і$ проблем великих даних. На основі використання запропонованих моделей і методів розроблено сервіс пошуку зображень по зображенню. За допомогою иьього сервісу поставлена серія більш ніж з 1000 пошукових експериментів у сховищі, де знаходиться більше 100000 зображень. В результаті була підтверджена ефективність запропонованого методу за критеріями точності і швидкості пошуку.

Ключові слова: цииррове зображення, шаблон кратної довжини, оцінювання міри схожості зображень, ивидкий пошук, сховище даних.

\section{Вступ}

Постановка проблеми. За сучасними оцінками тільки в Instagram завантажується близько 100000000 фотографій кожен день [1]. Всього ж щодня в мережі публікуються понад 3000000000 зображень і більше 700000 годин відео.

Наші особисті та корпоративні архіви, а також відомі фотобанки (наприклад, Shutterstock, Depositphotos та інші) збільшуються з наростаючими темпами [2].

Хоча, кількість зображень в кожному 3 них окремо порівняно не велика (вона вимірюється тисячами, рідко - мільйонами), якщо помножити цю кількість зображень на кількість архівів і на кількість користувачів [1], цифра вийде дуже значна.

Цифрові зображення / фотографії часто піддаються різним трансформаціям. Наприклад, стисненню, при зміні формату файлу [3-4], підвищенню яскравості [5-7], тонової корекції [8-10], а також багатьом іншим перетворенням [11-13], накладенню фільтрів і різноманітних ефектів.

Також фотографії часто дублюються в архівах i в різних сховищах; особливо в особистих архівах локально на пристроях і в хмарних сховищах.

Всі ці трансформації і дублювання значно збільшують і так колосальну кількість цифрових зображень в Інтернет.

У такій ситуації актуальною $є$ розробка ефективних моделей, методів, алгоритмів і інформацій- них технологій пошуку зображення типу "Image based search” в сховищах великих даних [14-15].

До таких моделей і методів пред'являється ряд вимог. Найголовніше, вони повинні працювати швидко [16-18]. Вони повинні забезпечувати пошук в реальному масштабі часу незалежно від розміру сховища зображень. Інакше для користувачів такий сервіс пошуку зображень буде просто марним. При цьому необхідно забезпечити високу якість пошуку, стійкість до трансформацій і спотворень; перш за все за рахунок інваріантності моделей [19-21]. А також за рахунок збалансованого врахування класичних моделей [5; 8; 22] і моделей обчислювального інтелекту [23-25].

Відносно проблеми ефективності пошуку в роботі [26] запропонована базова інваріантна модель зображення, застосування якої дозволяє забезпечувати якісний пошук зображення в умовах трансформацій, зашумлення і наявності схожих зображень.

Мета статті - спираючись на результати роботи [26], розробити метод швидкого пошуку зображень у сховищі великих даних.

\section{Виклад основного матеріалу}

\section{1. Попередній аналіз даних}

Аналіз сучасних джерел і широко використовуваних систем розпізнавання, робота яких пов'язана 3 порівнянням і пошуком зображень в сховищах великих даних, показує, що всі вони, переважно, оріє- 
нтовані на роботу з шаблоном фіксованої довжини [27-28]. Так, наприклад, класична система ідентифікації особистості по райдужній оболонці ока працює наступним чином (рис. 1, рис. 2).
На першому етапі знаходять внутрішню і зовнішню межі райдужної оболонки ока. Після роблять перетворення виділеного кільцеподібного сегмента райдужної оболонки в прямокутник, причому, фік-

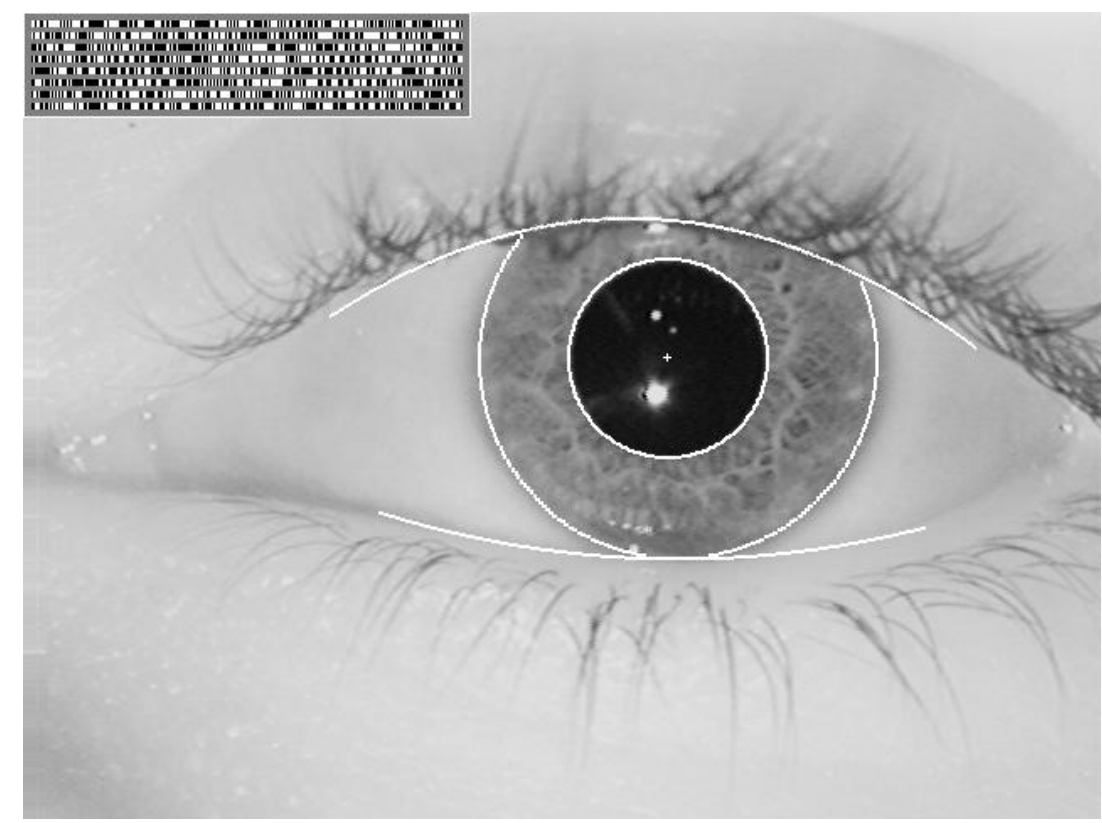

Рис. 1. Побудова бінарного шаблону фіксованої довжини по райдужці ока; шаблон фіксованої довжини в збільшеному масштабі представлений в лівому верхньому кутку Джерело: розроблено авторами за даними [27].

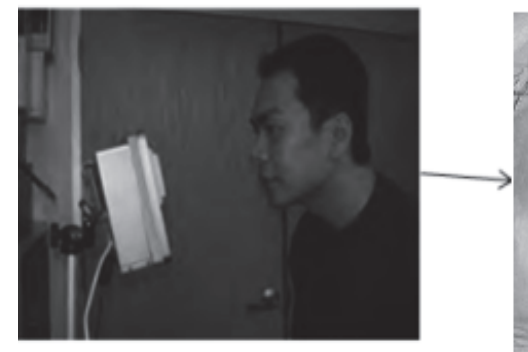

Image Acquisition

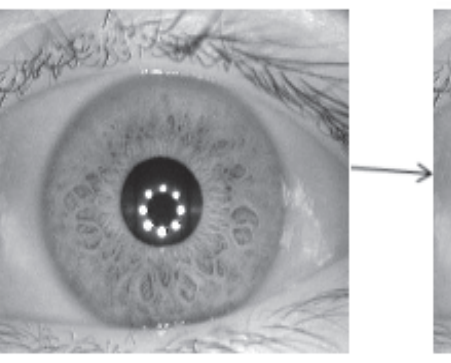

Localization

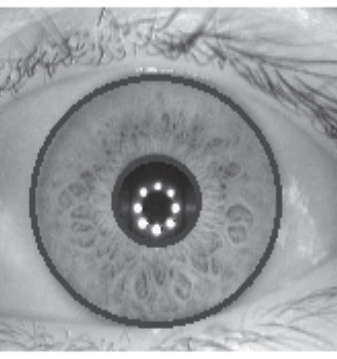

Segmentation

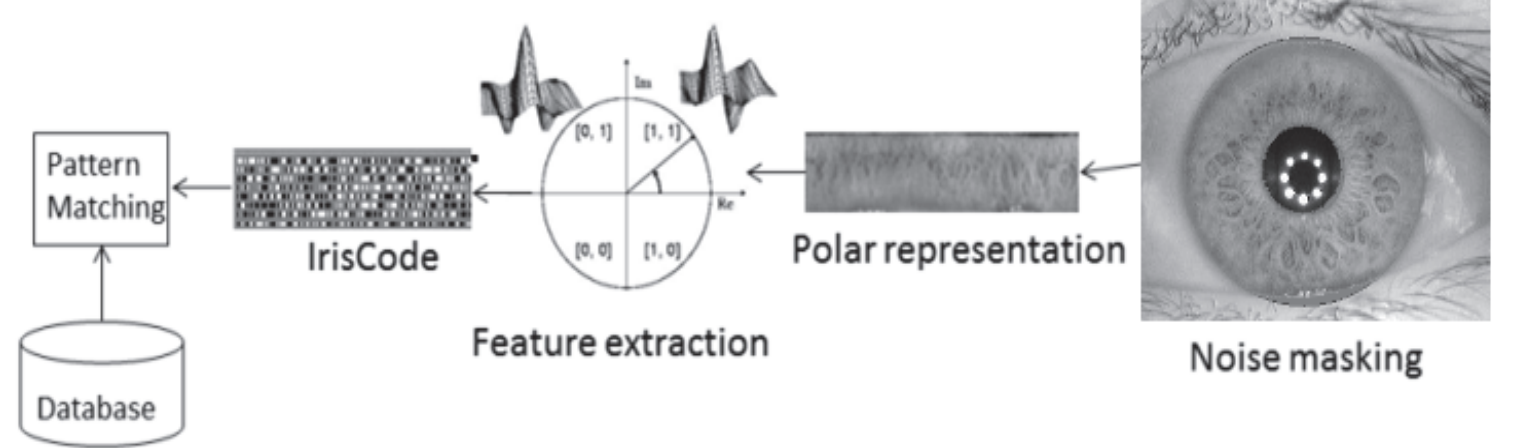

Рис. 2. Технологія розпізнавання особистості по райдужці ока, заснована на використанні шаблону фіксованої довжини Джерело: розроблено авторами за даними [28]. 
сованого розміру. Для спрощення подальшого аналізу при цьому часто роблять бінаризацію малюнка райдужки по заданому критерію (рис. 1).

У такому вигляді інформація про райдужці ока особистості зберігатися в базі даних системи ідентифікації особистості.

Зберігання шаблону (замість зберігання первинних зображень) дозволяє захищати персональні дані. Навіть якщо зловмисник отримає доступ до бази, він не зможе за шаблоном визначити власника.

Також наявність невеликого (в порівнянні з вихідним зображенням) шаблону дозволяє дуже швидко порівнювати його 3 аналогічними шаблонами інших зображень в базі і, таким чином, дуже швидко ідентифікувати особу. Без необхідності порівнювати великі вихідні зображення райдужної оболонки ока людини.

3 огляду на цей досвід, і досвід розробки інших систем біометричної ідентифікації для цілей роботи також будемо орієнтуватися на використання шаблону фіксованої довжини для представлення цифрового зображення. Особливості побудови та використання такого шаблону описуються нижче.

В даний час для різних цілей найчастіше використовують такі стандартні метрики: дисперсія, середньоквадратичне відхилення, середнє, метрики Чебишева і Хемминга [29]. У кожної метрики є свої переваги і недоліки.

Дисперсія є класичною метрикою в статистиці. Вона ефективно використовується, коли потрібно оцінювати групу відхилень в середньому; і не пропускати при цьому окремі значущі викиди / відхилення. Які нелінійно посилюються за рахунок зведення в квадрат. I нелінійно збільшують вихідне значення дисперсії.

Оцінка дисперсії має вигляд

$$
D=\frac{1}{n} \sum_{i=1}^{n}\left(x_{i}-y_{i}\right)^{2},
$$

де $x_{i}, y_{i}$ - відповідні компоненти векторів $x, y$, які ми порівнюємо (інакше кажучи, відповідні елементи двох шаблонів), а $n$ - розмірність векторів. Мається на увазі, що вектори мають однакову розмірність.

Середньоквадратичне відхилення (СКВ) використовується для оцінювання відхилення в середньому без нелінійного посилення окремих значущих відхилень.

Оцінка СКВ має вигляд

$$
S=\sqrt{D} .
$$

Метрика Чебишева важлива для таких ситуацій, коли важливо не пропустити екстремальні спостереження (коли фактична оцінка проводиться по максимальній розбіжності):

$$
D=\max \left|x_{i}-y_{i}\right| .
$$

3 метою практичного використання найчастіше застосовується оцінка розбіжності в середньому

$$
D=\frac{1}{n} \sum_{i=1}^{n}\left|x_{i}-y_{i}\right| .
$$

На відміну від розглянутих вище оцінок вона має лінійних характер і з обчислювальної точки зору набагато швидше.

Ще швидше працює метрика Хеммінга

$$
D=\sum_{i=1}^{n}\left|x_{i}-y_{i}\right| .
$$

В даний час ця метрика застосовується майже у всіх сучасних моделях обчислювального інтелекту [30-31].

3 такою метрикою зручно працювати в умовах попереднього нормування даних, коли:

$$
\left\{\begin{array}{l}
\sum_{i=1}^{n} x_{i}=1, \\
\sum_{i=1}^{n} y_{i}=1, \\
0<x_{i}<1, \\
0<y_{i}<1 .
\end{array}\right.
$$

В таких умовах $D$ може приймати значення на інтервалі $0<D<2$.

У такій ситуації для роботи 3 нормованими величинами на інтервалі $0<D<1$ формулу Хеммінга часто змінюють так

$$
D=\frac{1}{2} \sum_{i=1}^{n}\left|x_{i}-y_{i}\right| .
$$

Для досягнення максимальної швидкості пошуку на практиці найчастіше використовують метрику Хеммінга. Якщо спеціально не обумовлено інше, ми будемо чинити так само.

\section{2. Метод швидкого пошуку зображення}

В роботі [26] була запропонована інваріантна модель зображення, яка спеціально була розроблена для швидкого пошуку, формально представляється вектором чисел $g_{1 \times n}$.

На заключному етапі побудови такої моделі (етап агрегації) було зазначено, що кількість стовпчиків вибирається таким чином, щоб розмірність $n$ вектору відповідала максимально можливій ступені двійки: $2^{m}$.

Оскільки властивості зображень можуть значно відрізнятися, максимальний розмір $n$ для різних зображень також може значно відрізнятися.

У такій ситуації вибрати одне значення $n$ досить складно, оскільки велике $n$ дає високу якість, але може бути застосовано не до всіх зображень, а маленьке $n$ може бути застосовано до всіх зображень, але дає низьку якість порівняння зображень.

У такій ситуації шаблон фіксованої довжини 
побудувати не можна. Але можна побудувати шаблон кратної довжини. Іншими словами, найкраще рішення полягає в тому, щоб для кожного зображення вибирати максимально можливе значення $n$; перед порівнянням приводити шаблони до однієі розмірності шляхом швидкого складання суміжних частостей більшого по довжині шаблона.

Такий адаптивний підхід дозволить отримати максимальну якість порівняння в кожному конкретному випадку. При цьому операція приведення довжини шаблону дуже швидка.

Алгоритм порівняння двох шаблонів. Отже, припустимо, що у нас $є 2$ шаблони зображень $g_{1 \times n^{\prime}}$ та $g_{1 \times n "}$ для порівняння.

Крок 1. Приведення довжини шаблонів. Шаблони $g_{1 \times n^{\prime}}$ та $g_{1 \times n^{\prime \prime}}$ зводяться до меншого розміру $n$ (якщо $\left.n^{\prime} \neq n^{\prime \prime}\right)$, де $n=\min \left(n^{\prime}, n^{\prime \prime}\right)$. При цьому менша гістограма не змінюється. Більша гістограма зменшується шляхом складання по $l=\max \left(n^{\prime}, n^{\prime \prime}\right) / \min \left(n^{\prime}, n^{\prime \prime}\right)$ суміжних частостей.

Крок 2. Оцінка міри відмінності зображень. Міру відмінності двох гістограм оцінюємо відповідно формулі (7).

Модель зберігання і пошуку зображень. Зображення в архівах і сховищах даних можуть зберігатися будь-яким зручним чином.

Для організації ефективного пошуку на першому етапі необхідно перебрати всі зображення в сховище, побудувати для кожного 3 них шаблон $g_{1 \times n}$, зберегти всі ці шаблони в окремому сховищі шаблонів, взаємно-однозначно асоційованому зі сховищем зображень.

Максимальний розмір шаблону напівтонового зображення 256 значень. Реально ж, цей розмір рідко перевищує 64.

Розмір сучасного зображення, найчастіше, знаходиться в межах від 8 до 128 мегапікселів.

У такій ситуації сховище шаблонів буде займати незначну місце, в середньому, по порядку величини, в 100000 разів менше розміру сховища зображень.

Разом 3 тим, його наявність дозволить при порівнянні зображень відразу порівнювати шаблон шуканого зображення 3 шаблонами зображень у сховищі, забезпечуючи тим самим дуже високу швидкість пошуку.

На другому етапі можна застосовувати наступний метод швидкого пошуку зображення у сховищі.

Крок 1. Здається шукане зображення і визначається його шаблон $g_{1 \times n}$. Якщо це зображення з якогось сховища, шаблон вже побудований. В іншому випадку він повинен бути побудований [26].
Щоб не виконувати подібну роботу даремно, доцільно для всіх зображень, які вперше потрапляють в сховище / архів, відразу будувати шаблон $g_{1 \times n}$. Щоб обчислювати його один раз.

Крок 2. Порівнюємо шаблон шуканого зображення 3 шаблонами інших зображень у сховищі і оцінюємо дисперсію.

Використовуючи поріг на кількість зображень / на міру подібності залишаємо лише ті зображення, які подолали цей поріг.

Крок 3. Сортуємо зображення по зростанню дисперсії. Виводимо / відправляємо цей список в якості відповіді на запит.

Запропонований метод досить простий і ефективний в реалізації (практична реалізація і оцінки обчислювальної ефективності даються в наступному розділі).

Він дозволяє працювати з будь-якими архівами і сховищами даних, оскільки він їх не змінює, а лише створює додаткове сховище шаблонів.

Разом з тим, для ефективної реалізації пошуку необхідний постійний зв'язок сховища шаблонів зі сховищем зображень. Щоб оперативно реагувати на будь-які зміни в сховищі зображень (на додавання / видалення / переміщення файлу зображення).

Для підвищення швидкості обробки зображень 3 програмної точки зору доцільно організувати багатопотокове порівняння зображень. Навіть на стандартних комп'ютерах користувачів / телефонах / планшетах це від 2 до 16 разів підвищить швидкість обробки сховища зображень.

\section{3. Аналіз результатів експерименту}

На основі використання моделі, запропонованої в роботі [26], а також методу швидкого пошуку зображення в сховищі, розроблена відповідна інформаційна технологія і пошуковий сервіс типу "Image based service".

На рис. 3-5 наведені результати роботи запропонованого сервісу. Всього із застосуванням запропонованого сервісу була поставлена серія більш ніж з 1000 пошукових експериментів у сховищі, де понад 100000 зображень, які представляли близько 80 визначених класів об'єктів, включаючи обличчя людей, транспортні засоби, будівлі та споруди, і багато інших.

Експеримент ставився на стандартному призначеному для користувача персональному комп'ютері (ЦП Intel Core i7-8750H, 16 GВ ОЗУ). Для чистоти експерименту використовувався неоптимізований однопотоковий сервіс, написаний на Python. 3 його допомогою пошук зображення у сховищі здійснювався за 1.7 секунди. Відносна похибка часу пошуку при цьому не перевищувала $1 \%$. 


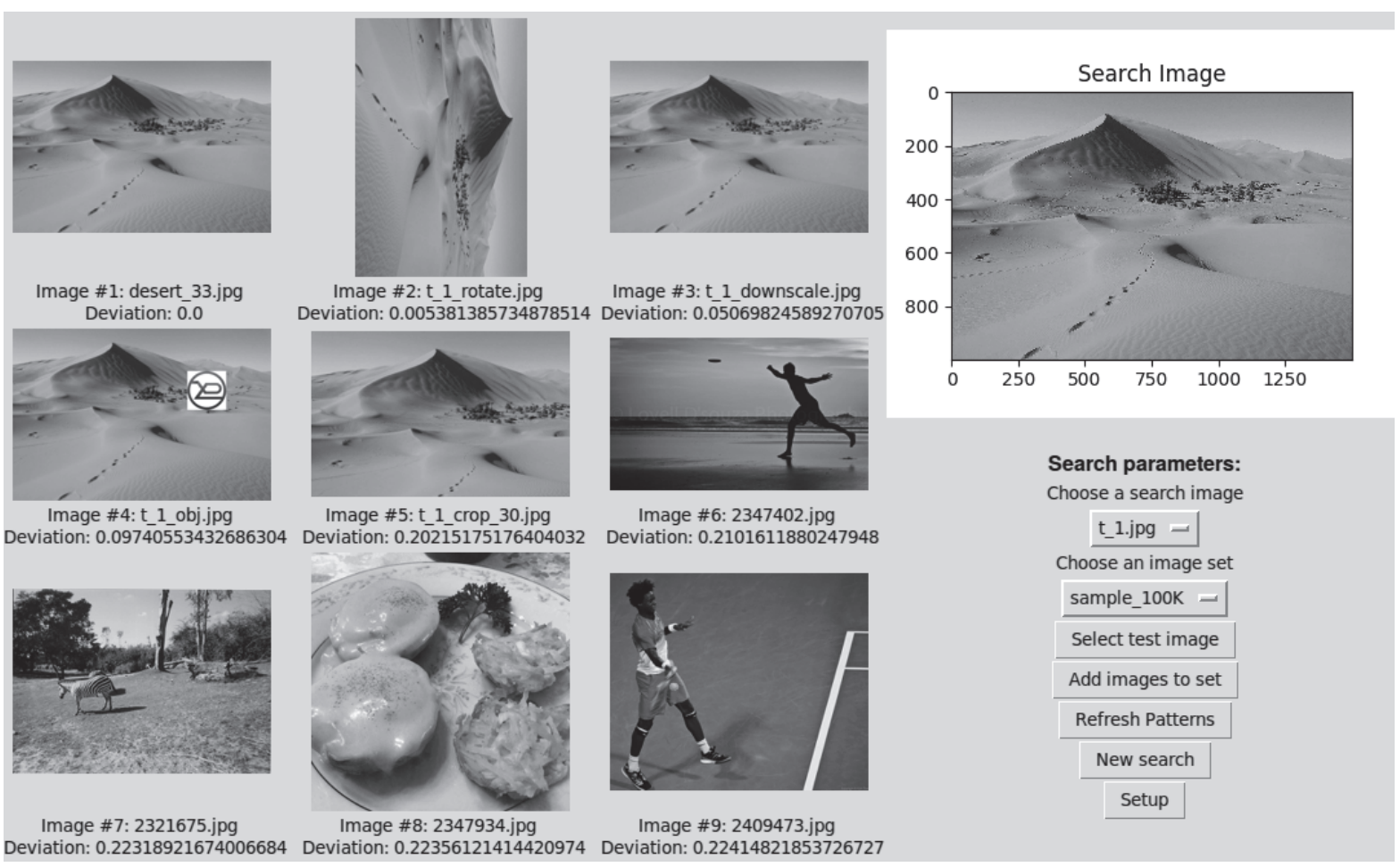

Рис. 3. Перші 9 зображень (відсортовані за зростанням дисперсіі), які найбільше схожі с зображенням пустелі, яке шукається (Search Image) [32] Джерело: розроблено авторами.

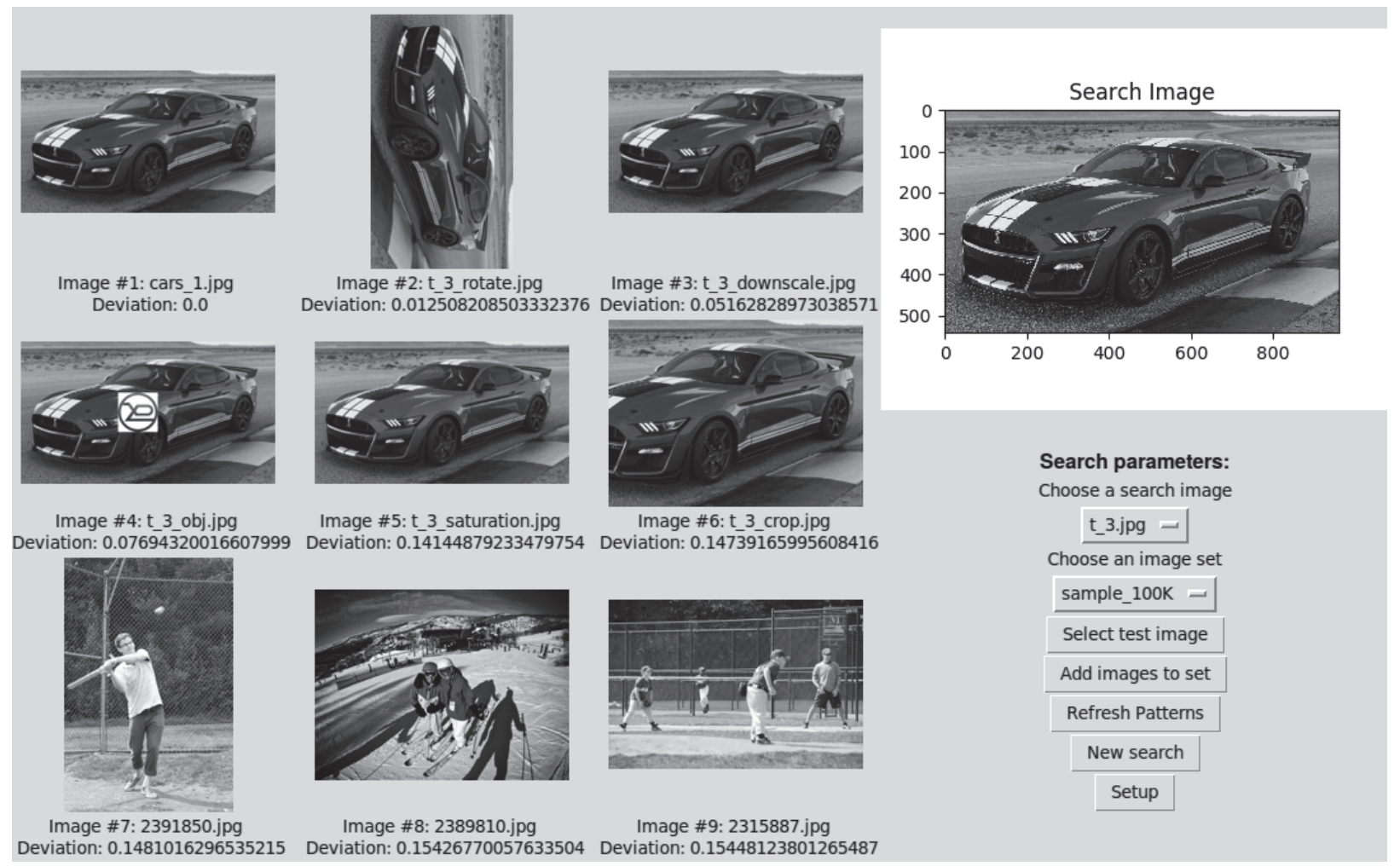

Рис. 4. Перші 9 зображень (відсортовані за зростанням дисперсії), які найбільше схожі с зображенням автомобіля, яке шукається (Search Image) Джерело: розроблено авторами за даними [33]. 


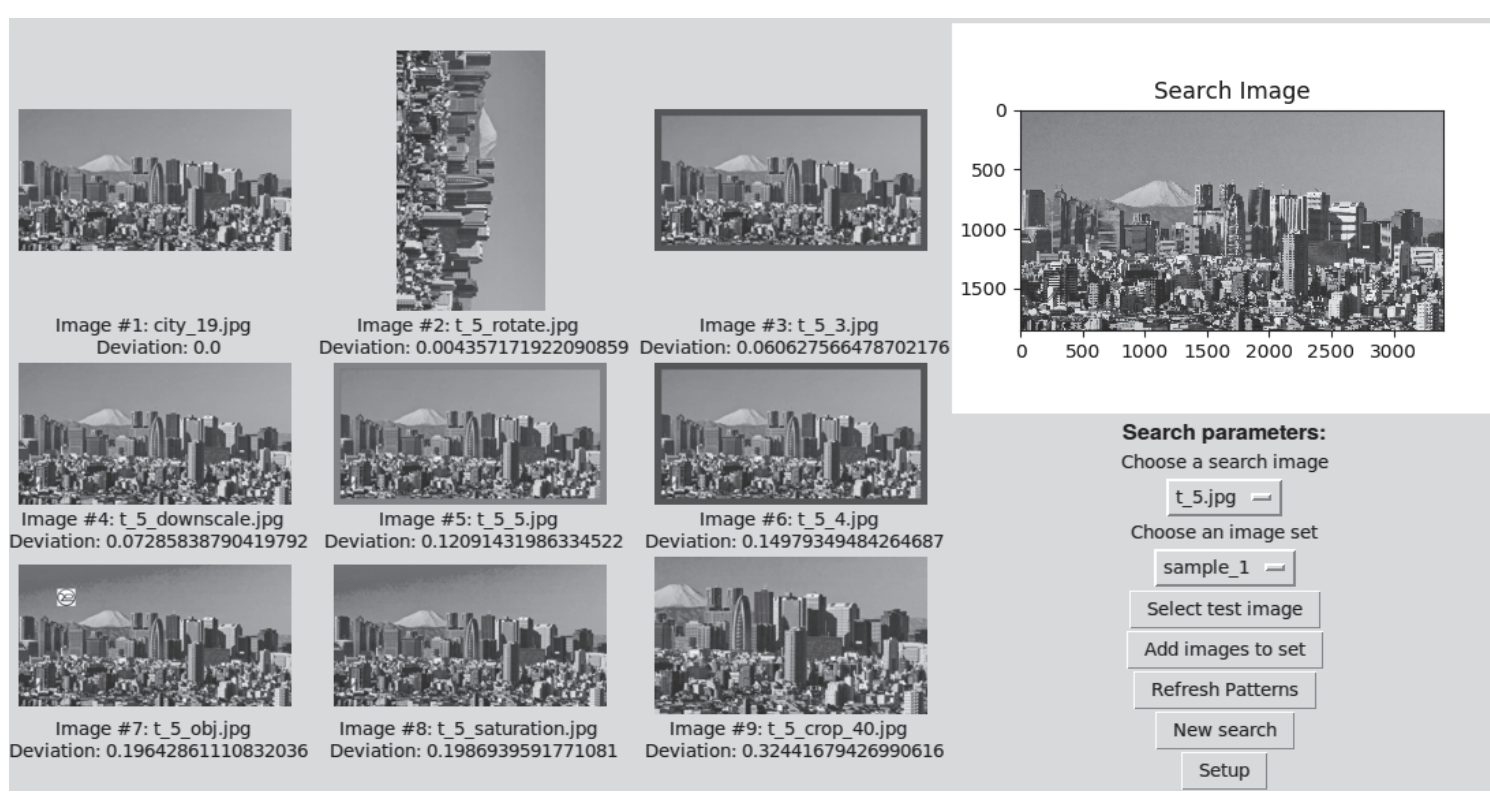

Рис. 5. Перші 9 зображень (відсортовані за зростанням дисперсіі), які найбільше схожі з зображенням міста, яке шукається (Search Image)

Джерело: розроблено авторами за даними [34].

\section{Висновки}

На основі аналізу моделей і принципів роботи сучасних систем біометричної ідентифікації і ряду широко відомих сервісів, пов'язаних з порівнянням і пошуком зображень, в роботі запропоновані:

- шаблон зображення кратної довжини, що швидко масштабується;

- ефективний алгоритм порівняння масштабованих шаблонів двох зображень і оцінювання міри схожості цих зображень;

- модель зберігання і пошуку зображення на основі використання масштабується шаблону;

- метод швидкого пошуку зображення у сховищі.

3 урахуванням моделі зображення, інваріантної до найбільш поширених перетворень зображень, запропонованої в роботі [26], запропоновані моделі і методи в комплексі дозволяють ефективно вирішити проблему пошуку зображень у сховищі великих даних по критеріях точності і часу. 3 урахуванням можливих трансформацій i дублювання зображень, наявності великої кількості схожих зображень і про- блем великих даних. На основі запропонованих в роботі моделей і методів для проведення експериментів був спеціально розроблений пошуковий сервіс (тип "Image based service"). Використовуючи цей сервіс, була виконана серія з більш ніж 1000 експериментів з пошуку зображень у сховищі, де знаходиться більше 100000 зображень, які представляли близько 80 різних класів об'єктів.

В результаті була підтверджена ефективність запропонованого підходу за критеріями точності i швидкості пошуку.

Запропонований метод швидкого пошуку може ефективно застосовуватися для різних класів зображень і сховищ, може бути легко адаптований для аналізу кольорових зображень, але лише за умови, що ці зображення характеризуються унікальною інформативною гістограмою яскравості.

Найближча перспектива розвитку запропонованого підходу (щодо моделей і методів пошуку) паралельна обробка зображень [35-37], адаптація на для пошуку кольорових зображень.

\section{Список літератури}

1. Офіційний сайт INTERNETLIVESTATS.COM. Internet live stats. - Режим доступу: https://www. internetlivestats.com (дата звернення: 14.03.2021).

2. Офіційний сайт BUFFER.COM. Buffer - 24+ Sites to Find Free Images You Would Actually Use for Your Marketing. - Режим доступу: https://buffer.com/library/free-images (дата звернення: 14.03.2021).

3. Гриньов Д.В. Методи стиснення зображень в системах цифрової обробки даних / Д.В. Гриньов, 3.3. Закір // Системи обробки інформації. - 2010. - № 2(83). - С. 66-70.

4. О влиянии алгоритма сжатия JPEG-2000 на статические характеристики изображения / А.И. Стрелков, С.Е. Кальной, Т.А. Стрелкова, Е.А. Соломко // Системи обробки інформації. - 2008. - № 5(72). - С. 116-119.

5. Gonzalez R.C. Digital Image Processing / R.C. Gonzalez, R.E. Woods. - Hoboken: Prentice Hall, 2018. - 1168 p.

6. Шапиро Л. Компьютерное зрение / Л. Шапиро, Дж. Стокман. - М.: БИНОМ, 2006. - 752 с. 
7. Forsyth D.A. Computer Vision: A Modern Approach / D.A. Forsyth, J. Ponce. - London: Pearson Education Limited, 2015. - $792 \mathrm{p}$.

8. Gradational Correction Models Efficiency Analysis of Low-Light Digital Image / K. Smelyakov, A. Chupryna, M. Hvozdiev, D. Sandrkin // Open Conference of Electrical, Electronic and Information Sciences (eStream). - Vilnius, 25-25 April 2019. - P. 1-6.

9. Efficiency of Image Convolution / K. Smelyakov, M. Shupyliuk, V. Martovytskyi, D. Tovchyrechko, O. Ponomarenko // 2019 IEEE 8th International Conference on Advanced Optoelectronics and Lasers (CAOL). - Sozopol, 6-8 September 2019. P. 578-583.

10. Comparative efficiency analysis of gradational correction models of highly lighted image / K. Smelyakov, A. Chupryna, M. Hvozdiev, D. Sandrkin, V. Martovytskyi // IEEE International Scientific-Practical Conference Problems of Infocommunications, Science and Technology (PIC S\&T). - Kyiv, 8-11 October 2019. - P. 703-708.

11. Corke P. Robotics, Vision and Control / P. Corke. - Berlin: Springer, 2017. -693 p.

12. Яне Б. Цифровая обработка изображений / Б. Яне. - М.: Техносфера, 2007. - 584 с.

13. Sonka M. Image processing, analysis and machine vision / M. Sonka. - Wisconsin: CP Company, 1999. $-770 \mathrm{p}$.

14. Офіційний сайт TINEYE.COM. Тineye. - Режим доступу: https://tineye.com (дата звернення: 14.03.2021).

15. Офіційний сайт SAP.COM. SAP, Image-Based Buying. - Режим доступу: https:/help.sap.com/viewer/0dcea07c6f964aab88966807f1891ba0/1905/en-US/77ca1dbbb9e4469cb73345d4df8bc639.html (дата звернення: 14.03.2021).

16. The 3 Types of Image Search Engines. - Режим доступу: https:/www.pyimagesearch.com/2014/01/15/the-3-types-ofimage-search-engines-search-by-meta-data-search-by-example-and-hybrid/ (дата звернення: 14.03.2021).

17. Magda E.F. Image search algorithms / E.F. Magda, Ș. Cosmin, L.A. Ioan // 7th International Conference on Electronics, Computers and Artificial Intelligence. - Bucharest: 25-27 June 2015. - P. 35-40.

18. Image Search Algorithm in Local Data Base / O.A. Bodrov, A.S. Tarasov, V.Y. Tarasova, I.V. Bodrova // 8th Mediterranean Conference on Embedded Computing. - Budva, 10-14 June 2019, P. 1-3.

19. Si J. Age-invariant face recognition using a feature progressing model / J. Si, W. Li // 3rd IAPR Asian Conference on Pattern Recognition. - Kuala Lumpur, 3-6 November 2015. - P. 775-780.

20. Maw H.M. Face Recognition based on Illumination Invariant Techniques Model / H.M. Maw, S.M. Thu, M.T. Mon // International Conference on Advanced Information Technologies. - Yangon, 6-7 November 2019. - P. 120-125.

21. Dimension Invariant Model for Human Head Detection / S.D. Khan, H. Ullah, M. Ullah, F.A. Cheikh, A. Beghdadi // 8th European Workshop on Visual Information Processing. - Roma, 28-31 October 2019. - P. 99-104.

22. Jain S. Image based search engine using deep learning / S. Jain, J. Dhar // Tenth International Conference on Contemporary Computing. - Noida, 10-12 August 2017. - P. 1-7.

23. Goodfellow I. Deep Learning / I. Goodfellow, Y. Bengio, A. Courville. - Cambridge: MIT Press, 2016. - 787 p.

24. Norvig P. Artificial Intelligence: A Modern Approach, Global Edition / P. Norvig, S. Russell. - London: Pearson Education Limited, 2016. - $1152 \mathrm{p}$.

25. Reverse Image Search for the Fashion Industry Using Convolutional Neural Networks / K.F. Mawoneke, X. Luo, Y. Shi, K. Kita // 5th International Conference on Signal and Image Processing. - Nanjing, 23-25 October 2020. - P. 483-489.

26. Розробка інваріантної моделі цифрового зображення для швидкого пошуку у сховищах даних / К.С. Смеляков, А.С. Чуприна, Д.Л. Сандркін, Є.В. Вакулік, С.М. Дроб // Збірник наукових праць Харківського національного університету Повітряних Сил. - 2021. - № 2(68). - С. 108-115. https://doi.org/10.30748/zhups.2021.68.14.

27. Introduction to Iris Recognition [Електронний pecypc]. - Режим доступу: https://www.cl.cam.ac.uk/ jgd1000/iris_recognition.html (дата звернення: 14.03.2021).

28. Iris recognition system following Daugman's approach [Електронний pecypc]. - Режим доступу: https://www.researchgate.net/figure/Overview-of-an-iris-recognition-system-following-Daugmans-approach-17_fig1_303021427 (дата звернення: 14.03.2021).

29. Metrics [Електронний ресурс]. - Режим доступу: numerics.mathdotnet.com/Distance.html (дата звернення: 14.03.2021).

30. Xiang J. Joint Face Detection and Facial Expression Recognition with MTCNN / J. Xiang, G. Zhu // 4th International Conference on Information Science and Control Engineering. - Changsha, 21-23 July 2017. - P. 424-427.

31. Ma M. Multi-View Face Detection and Landmark Localization Based on MTCNN / M. Ma, J. Wang // Chinese Automation Congress. - Xi'an, 30 November-2 December 2018. - P. 4200-4205.

32. Landvorm [Електронний ресурс]. - Режим доступу: https:/nl.wikipedia.org/wiki/Landvorm\#/media/ Bestand:Erg Chebbi_Maroc.jpg (дата звернення: 14.03.2021).

33. The Ford Shelby GT500 is the most powerful street-legal [Електронний ресурс]. - Режим доступу: https://www.insider.com/the-ford-shelby-gt500-mustang-photos-features-specs-2019-8 (дата звернення: 14.03.2021).

34. Skyscrapers of Shinjuku 2009 January [Електронний ресурс]. - Режим доступу: https://uk.wikipedia.org/ wiki/\%D0\%A4\%D0\%B0\%D0\%B9\%D0\%BB:Skyscrapers_of_Shinjuku_2009_January_(revised).jpg (дата звернення: 14.03.2021).

35. Parallel Image Stitching Based on Multithreaded Processing on GPU / O. Nakov, E. Mihaylova, M. Lazarova, V. Mladenov // International Conference on Intelligent and Innovative Computing Applications. - Mon Tresor, 6-7 December 2018. - P. 1-5. 
36. Multithreading Method to Perform the Parallel Image Registration / L. Chen, J. Li, J. Zhou, M. Jiang // International Conference on Computational Intelligence and Software Engineering. - Wuhan, 11-13 December 2009. - P. 1-4.

37. Liu Y. Parallel Implementations of Image Processing Algorithms on Multi-Core / Y. Liu, F. Gao // Fourth International Conference on Genetic and Evolutionary Computing. - 2010. - No. 1. - P. 71-74.

\section{References}

1. The official site of INTERNETLIVESTATS.COM (2021), Internet live stats, available at: www. internetlivestats.com (accessed 14 March 2021).

2. The official site of BUFFER.COM. Buffer - 24+ Sites to Find Free Images You Would Actually Use for Your Marketing, available at: https://buffer.com/library/free-images (accessed 14 March 2021).

3. Grin'ov, D.V. and Zakir, Z.Z. (2010), "Metodi stisnennya zobrazhen' v sistemah cifrovoï obrobki danih" [Methods of image compression in digital data processing systems], Information Processing Systems, No. 2(83), pp. 66-70.

4. Strelkov, A.I., Kal'noj, S.E., Strelkova, T.A. and Solomko, E.A. (2008), “O vliyanii algoritma szhatiya JPEG-2000 na staticheskie harakteristiki izobrazheniya" [On the influence of the JPEG-2000 compression algorithm on the static characteristics of the image], Information Processing Systems, No. 5(72), pp. 116-119.

5. Gonzalez, R.C. and Woods, R.E. (2018), Digital Image Processing, Prentice Hall, Hoboken, 1168 p.

6. Shapiro, L. and Stokman, Dzh. (2006), “Komp'yuternoe zrenie” [Computer vision], BINOM, Moscow, 752 p.

7. Forsyth, D.A. and Ponce, J. (2015), A Modern Approach, Pearson Education Limited, London, 792 p.

8. Smelyakov, K., Chupryna, A., Hvozdiev, M. and Sandrkin, D. (2019), Gradational Correction Models Efficiency Analysis of Low-Light Digital Image, Open Conference of Electrical, Electronic and Information Sciences (eStream), 25-25 April, Vilnius, pp. 1-6.

9. Smelyakov, K., Shupyliuk, M., Martovytskyi, V., Tovchyrechko, D. and Ponomarenko, O. (2019), Efficiency of Image Convolution, IEEE 8th International Conference on Advanced Optoelectronics and Lasers (CAOL), 6-8 September, Sozopol, P. 578-583.

10. Smelyakov, K., Chupryna, A., Hvozdiev, M., Sandrkin, D. and Martovytskyi, V. (2019), Comparative efficiency analysis of gradational correction models of highly lighted image, IEEE International Scientific-Practical Conference Problems of Infocommunications, Science and Technology (PIC S\&T), 8-11 October, Kyiv, P. 703-708.

11. Corke, P. (2017), Robotics, Vision and Control, Springer, Berlin, 693 p.

12. Yane, B. (2007), “Cifrovaya obrabotka izobrazhenij” [Digital image processing], Tekhnosfera, Moscow, $584 \mathrm{p}$.

13. Sonka, M. (1999), Image processing, analysis and machine vision, CP Company, Wisconsin, 770 p.

14. The official site of TINEYE.COM, Tineye, available at: https://tineye.com (accessed 14.03.2021).

15. The official site of SAP.COM. SAP, Image-Based Buying, available at: https://help.sap.com/viewer/0dcea07c6f964aab88966807f1891ba0/1905/en-US/77ca1dbbb9e4469cb73345d4df8bc639.html (accessed 14 March 2021).

16. (2014), The 3 Types of Image Search Engines, available at: www.pyimagesearch.com/2014/01/15/the-3-types-ofimage-search-engines-search-by-meta-data-search-by-example-and-hybrid/ (accessed 14 March 2021).

17. Magda, E.F., Cosmin, Ș. and Ioan, L.A. (2015), Image search algorithms, 7th International Conference on Electronics, Computers and Artificial Intelligence, 25-27 June, Bucharest, pp. 35-40.

18. Bodrov, O.A., Tarasov, A.S., Tarasova, V.Y. and Bodrova, I.V. (2019), Image Search Algorithm in Local Data Base, 8th Mediterranean Conference on Embedded Computing, 10-14 June, Budva, pp. 1-3.

19. Si, J. and Li, W. (2015), Age-invariant face recognition using a feature progressing model, 3rd IAPR Asian Conference on Pattern Recognition, 3-6 November, Kuala Lumpur, pp. 775-780.

20. Maw, H.M., Thu, S.M. and Mon, M.T. (2019), Face Recognition based on Illumination Invariant Techniques Model, International Conference on Advanced Information Technologies, 6-7 November, Yangon, pp. 120-125.

21. Khan, S.D., Ullah, H., Ullah, M., Cheikh, F.A. and Beghdadi, A. (2019), Dimension Invariant Model for Human Head Detection, 8th European Workshop on Visual Information Processing, 28-31 October, Roma, pp. 99-104.

22. Jain, S. and Dhar, J. (2017), Image based search engine using deep learning, Tenth International Conference on Contemporary Computing, 10-12 August, Noida, pp. 1-7.

23. Goodfellow, I., Bengio, Y. and Courville, A. (2016), Deep Learning, MIT Press, Cambridge, 787 p.

24. Norvig, P. and Russell, S. (2016), Artificial Intelligence: A Modern Approach, Global Edition, Pearson Education Limited, London, $1152 \mathrm{p}$.

25. Mawoneke, K.F., Luo, X., Shi, Y. and Kita, K. (2020), Reverse Image Search for the Fashion Industry Using Convolutional Neural Networks, 5th International Conference on Signal and Image Processing, 23-25 October, Nanjing, pp. 483-489.

26. Smelyakov, K.S., Chuprina, A.S., Sandrkin, D.L., Vakulik, Ye.V. and Drob, Ye.M. (2021), "Rozrobka invariantnoï modeli cifrovogo zobrazhennya dlya shvidkogo poshuku u skhovishchah danih" [Development of an invariant digital image model for quick search in data warehouses], Scientific Works of Kharkiv National Air Force University, No. 2(68), pp. 108-115. https://doi.org/10.30748/zhups.2021.68.14.

27. Introduction to Iris Recognition, available at: www.cl.cam.ac.uk/ jgd1000/iris_recognition.html (accessed 14 March 2021).

28. Iris recognition system following Daugman's approach, available at: www.researchgate.net/figure/Overview-of-an-irisrecognition-system-following-Daugmans-approach-17_fig1_303021427 (accessed 14 March 2021).

29. Metrics, available at: numerics.mathdotnet.com/Distance.html (accessed 14 March 2021). 
30. Xiang, J. and Zhu, G. (2017), Joint Face Detection and Facial Expression Recognition with MTCNN, 4th International Conference on Information Science and Control Engineering, 21-23 July, Changsha, pp. 424-427.

31. Ma, M. and Wang, J. (2018), Multi-View Face Detection and Landmark Localization Based on MTCNN, Chinese Automation Congress, 30 November-2 December, pp. 4200-4205. 2021).

32. Landvorm, available at: nl.wikipedia.org/wiki/Landvorm\#/media/Bestand:Erg_Chebbi_Maroc.jpg (accessed 14 March

33. The Ford Shelby GT500 is the most powerful street-legal, available at: www.insider.com/the-ford-shelby-gt500mustang-photos-features-specs-2019-8 (accessed 14 March 2021).

34. Skyscrapers of Shinjuku 2009 January, available at: uk.wikipedia.org/wiki/\%D0\%A4\%D0\% B0\%D0\%B9\%D0\%BB:Skyscrapers_of_Shinjuku_2009_January_(revised).jpg (accessed 14 March 2021).

35. Nakov, O., Mihaylova, E., Lazarova, M. and Mladenov, V. (2018), Parallel Image Stitching Based on Multithreaded Processing on GPU, International Conference on Intelligent and Innovative Computing Applications, 6-7 December, Mon Tresor, pp. $1-5$.

36. Chen, L., Li, J., Zhou, J. and Jiang, M. (2009), Multithreading Method to Perform the Parallel Image Registration, International Conference on Computational Intelligence and Software Engineering, 11-13 December, Wuhan, pp. 1-4.

37. Liu, Y. and Gao, F. (2010), Parallel Implementations of Image Processing Algorithms on Multi-Core, Fourth International Conference on Genetic and Evolutionary Computing, No. 1, pp. 71-74.

Надійшла до редколегії 26.03.2021

Схвалена до друку 12.05.2021

\section{Відомості про авторів:}

Смеляков Кирило Сергійович доктор технічних наук професор професор кафедри Харківського національного університету радіоелектроніки, Харків, Україна

https://orcid.org/0000-0001-9938-5489

\section{Сандркін Денис Леонідович} аспірант Харківського національного університету радіоелектроніки, Харків, Україна https://orcid.org/0000-0002-3542-5194

\section{Товчиречко Дарія Олегівна}

аспірант Харківського національного університету радіоелектроніки, Харків, Україна

https://orcid.org/0000-0002-1196-5559

\section{Вакулік Свген Вікторович}

магістр Харківського національного університету радіоелектроніки, Харків, Україна

https://orcid.org/0000-0002-4940-0529

\section{Дроб Свген Маркович}

кандидат технічних наук доцент кафедри

Харківського національного

університету Повітряних Сил ім. І. Кожедуба

Харків, Україна

http://orcid.org/0000-0002-2015-220X

\section{Information about the authors:}

Kyrylo Smelyakov

Doctor of Technical Sciences Professor

Professor of Department

of Kharkiv National University of Radio Electronics, Kharkiv, Ukraine

https://orcid.org/0000-0001-9938-5489

\author{
Denys Sandrkin \\ Doctoral Student \\ of Kharkiv National University of Radio Electronics, \\ Kharkiv, Ukraine \\ https://orcid.org/0000-0002-3542-5194
}

\section{Dariia Tovchyrechko}

Doctoral Student

of Kharkiv National University of Radio Electronics, Kharkiv, Ukraine

https://orcid.org/0000-0002-1196-5559

\author{
Eugen Vakulik \\ Master \\ of Kharkiv National University of Radio Electronics, \\ Kharkiv, Ukraine \\ https://orcid.org/0000-0002-4940-0529
}

\section{Yevhen Drob}

$\mathrm{PhD}$ in Technical Sciences Senior Lecturer of Department of Ivan Kozhedub Kharkiv

National Air Force University,

Kharkiv, Ukraine,

http://orcid.org/0000-0002-2015-220X

\section{РАЗРАБОТКА МЕТОДА БЫСТРОГО ПОИСКА ЦИФРОВОГО ИЗОБРАЖЕНИЯ В ХРАНИЛИЩАХ ДАННЫХ}

К.С. Смеляков, Д.Л. Сандркин, Д.О. Товчиречко, Е.В. Вакулик, Е.М. Дроб

На основе анализа моделей и принципов работы современных поисковых сервисов, связанных со сравнением и поиском изображений, в статье предложены шаблон изображения кратной длины, эффективный алгоритм сравнения шаблонов двух изображений и оченивания меры сходства этих изображений, модель хранения и поиска изображений на основе использования шаблонов, метод быстрого поиска изображения в хранилище на основе использования шаблона. С учетом предложенной модели изображения, инвариантной наиболее распространенным преобразованиям изображений, предложенные модели и методы в комплексе позволяют эффективно решить проблему поиска изображений в хранилище больших данных по критериям точности и времени. С учетом возможных трансформаций и дублирования изо- 
бражений, наличия большого количества похожих изображений и проблем больших данных. На основе использования предложенных моделей и методов разработан сервис поиска изображений по изображению. На основе использования этого сервиса поставлена серия более чем из 1000 поисковых экспериментов в хранилище, где находится более 100000 изображений. В результате была подтверждена эффективность предложенного метода по критериям точности и скорости поиска.

Ключевые слова: ичфровое изображение, шаблон кратной длины, оценивание меры сходства изображений, быстрый поиск, хранилище данных.

\section{DEVELOPMENT OF A METHOD FOR QUICK SEARCH OF DIGITAL IMAGES IN DATA STORAGES}

K. Smelyakov, D. Sandrkin, D. Tovchyrechko, E. Vakulik, Ye. Drob

The purpose of this article is to develop a method for quick search of a halftone image in a big data warehouse. Based on the analysis of models and principles of operation of modern search services related to the comparison and search of images, the article proposes an image template of multiple length, an effective algorithm for comparing templates of two images and evaluating the measure of similarity of these images, a model for storing and searching images based on the use of templates, a method quick search for images in the repository, based on the use of a template. Considering the proposed image model, which is invariant to the most common image transformations, the proposed models and methods in the complex can effectively solve the problem of image search in the big data storage by the criteria of accuracy and time. Taking into account possible transformations and duplication of images, the presence of a large number of similar images and the problems of big data. Based on the use of the proposed models and methods, an information technology, and a service for image search by image have been developed. Based on the use of this service, a series of more than 1000 search experiments has been executed on the repository, where more than 100,000 images are located. Which represented about 80 predefined classes of objects, including people's faces, vehicles, buildings and structures, and many others. As a result, the effectiveness of the proposed approach was confirmed in terms of accuracy and search speed. The proposed fast search method can be effectively applied to various classes of images and storages; it can be easily adapted for analyzing color images, but only if these images are characterized by a unique informative histogram of brightness.

Keywords: digital image, multiple length pattern, image similarity measure estimation, quick search, data warehouse. 